Int. J. Speleol. 23, 1-2 (1994): 13-17

\title{
MANAGEMENT OF SOME UNUSUAL FEATURES IN THE SHOW CAVES OF THE UNITED STATES
}

\author{
Jeanne Gurnee*
}

\begin{abstract}
SUMMARY
Protection of the unusual features in some of the 200 show caves of the U.S. have required innovative management. The sea caves of both the east and west coasts present the need for special preservation methods. Throughout the nation sometimes glass enclosures, vehicles and boats are used to separate visitors from sensitive cave features. Lighting and cleaning techniques have been studied and altered to discourage growth of algae. Some show caves are protected by double glass entrance and exit doors. Many caves, particularly on public lands, are closed during the hibernation period of endangered bats. In a number of caves, Native Americans have left artifacts and other evidences of their early visits, which have either been preserved in situ or relocated at appropriate archival sites.

The paper gives in more details specific caves and methods for the preservation of particular unique features.
\end{abstract}

\section{RIASSUNTO \\ [La gestione di alcune caratteristiche insolite nelle grotte turistiche degli USA]}

La protezione di attrattive insolite in alcune delle 2 grotte turistiche degli USA ha richiesto una gestione di tipo innovativo. Le grotte marine sia della costa orientale che di quella occidentale richiedono metodi di prevenzione del tutto appropriati. A seconda dei casi sono state impiegati ripari di vetro, veicoli e natanti per separare i visitatori dagli oggetti più a rischio.

Sono state studiate ed adattate allo scopo tecniche di illuminazione e di pulizia in modo da ostacolare la crescita delle alghe. Alcune grotte turistiche sono protette da doppie porte di vetro di ingresso ed uscita. Molte grotte, specialmente quelle aprentesi su terreno pubblico, vengono chiuse durante il periodo di ibernazione dei pipistrelli a rischio di estinzione. In varie grotte, popolazioni autoctone americane hanno lasciato segni od oggetti della loro presenza, che sono stati conservati sul luogo o trasferiti in appositi luoghi di raccolta.

Questo lavoro descrive, infine, con maggior dettaglio, grotte e metodi specifici per la protezione di alcune particolarita, uniche nel loro genere.

As we begin the work of the International Show Caves Association in November, 1990, one of the important values of the organization will be the exchange of information among nations and the discussion of scientific and other processes that contribute to cave preservation.

This first meeting provides an opportunity to show some of the unusual features in the caves of the United States and also to show some of the conservation techniques being employed, which probably parallel some of those being used elsewhere in the world.

Methods for the exhibition of caves in the U.S. depend not only on the technical steps that were used during their modification and development as

\footnotetext{
* 231 Irving Avenue, Closter, New Jersey 07624 USA
} 
show caves; but developers and administrators also consider climate, topography, demographics and other factors.

If we were to consider a map of the United States, we note that the eastern half of the U.S. has a climate similar to Europe and has a relatively heavy population density. the extreme southern states are warmer and subtropical. Farther to the south is the U.S. island of Puerto Rico which contains several show caves in the heavily vegetated tropical karst region. The western half of the U.S. is more arid, and the population density is much less between mid-America and the west coast.

The morphology of the east cost of the country reveals the small boulder caves near the coast, which were created as a result of the rocks that were deposited by glaciers. As we move west, we note the old, glacierworn Appalachian Mountains, the deserts and arid lands, a band of volcanos and lava tubes, the smaller limestone caves of California and Oregon, and finaly the sea caves on the west coast.

There are over 200 show caves in the U.S. and most are privately owned; however, there are also a good number on federal public lands and in national and state parks (Fig. 1). A look at the limestone areas would of course show a correlation to the topography.

Under the rolling farmlands and woodlands of eastern U.S. are many fine caves. Because of the population density, methods for accommodating visitors and at the same time protecting the caves are employed. One of these occurs in Ohio Caverns, where the snow-white speleothems are protected because the visitor walks on a trail that is more than a meter below the level of the original floor. The positioning allows excellent viewing of the formations, but is effective in discouraging any contact with them.

Vehicles that transport visitors effectively avoid the possibility of vandalism and in Penn's Cave in Pennsylvania visitors travel the complete cave tour by boat. In Fantastic Caverns, Missouri, the entire tour is made by vehicle. This allows formations to remain clean without the blackening effect made from the oils of hands caused by people who might touch them while walking along trails.

In the country's mid-section are some of the largest and and most impressive caves. The most well known is Mammoth Cave in Kentucky, the longest cave in the world, with over 300 miles of passageway. This cave is visited by almost a half million people a year, with over 2 million people visiting Mammoth Cave National Park. Numbers of visitors are limited on some cave trips to maintain the conditions necessary to sustain cave life, including blind fish and other cave-oriented species.

Many caves in the central states of Missouri, Tennessee and Arkansas sustain cave animals which are monitored by biologists from the National Speleological Society. In Missouri, for example, cave life is monitored in the lakes of Meramec Caverns, and isopods, salamanders, crayfish and other species are recorded in Onondaga and Cathedral Caverns. Blanchard Springs Caverns, operated by the US Forest Service, is sensitively developed and also monitored for the protection of its cave animals which include the Ozark blind salamander which lives in the lower passages. 


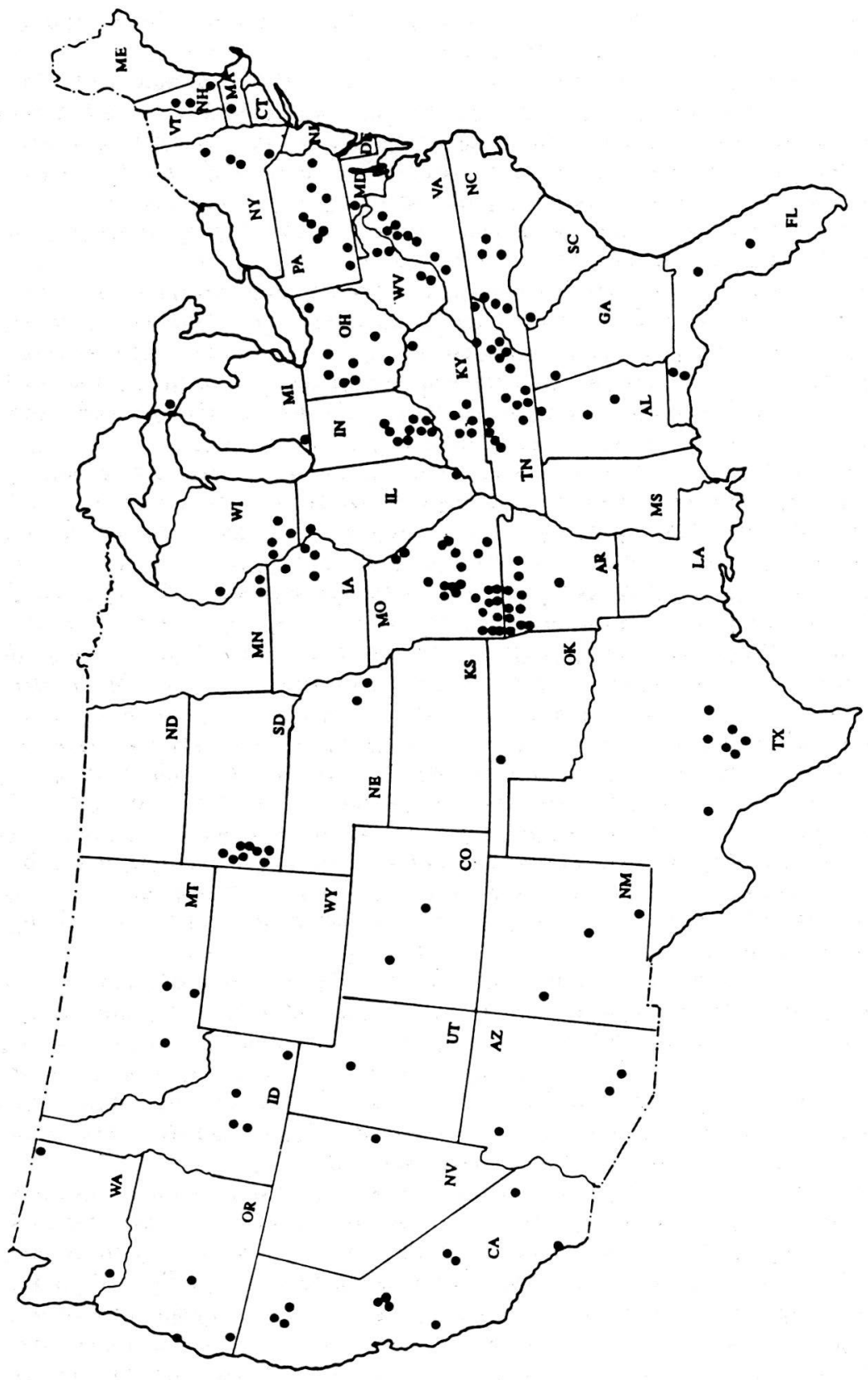


Caves throughout the country have made the transition from brightly colored lighting to the use of white lights to accurately display the colors of the calcite, contrasted with the areas influenced by iron oxide and other minerals. Because of the quantity of lampenflora produced when bright lights had to be left on in times of heavy visititation, specialists now suggest more subdued cave lighting that not only cuts down on the growth of algae but also gives the visitor a greater feeling of the cavern environment.

In Europe, many people have enjoyed concerts in such caves as Postojna or Frasassi. In the U.S. is Cumberland Caverns, Tennessee, which presents concerts and banquets. Some may feel the environment has been changed considerably in order to house a chandelier 40 feet overhead, as well as and other needs of man; however, except for this cave's dining room and area of the tour, over 23 miles of cave passageway remain un-disturbed. When a very small portion of a cave is developed, the remainder is protected in its wild condition, a common preservation technique. A map of Wind Cave, South Dakota, for example, shows more than 50 miles of National Monument cave untouched and only a small portion exhibited to the public.

The original planning process, the master plan, is an important factor in the exhibition and preservation of caves. Past difficulties are avoided by accurate master plans, now required by many governments, that encourage planning that avoids black top parking areas over caves, for example. Porous surfaces and natural surface vegetation allow percolating waters to penetrate as before. Sewage treatment is carefully engineered, and all surface construction and buildings are designed with the cave's health in mind.

On the island of Puerto Rico, the master plan for a cave development encludes a two-kilometer-long tropical ravine. To avoid hauling construction materials trough the tropical forest that leads to the cave, a 70-meter-high temporary construction elevator was built in a sinkhole at the back of the cave. All workers and equipment were transported to cave level by this route. The elevator preserved not only the tropical forest but also the natural entrance and its vegetation. Rare blind cave crustaceans, the Allewekia gurneii still live in the waters of the developed cave.

The co-existence of visitors with cave life is common throughout the show caves of the U.S. and bat programs are numerous. Cave administrators plan cave tours to fit the hibernation and migration seasons of bats and are open to visitors only after bats have migrated or have ended hibernation. To educate visitors about the beneficial life styles of bats, brochures are prepared by some cave owners as well as the National Speleological Society so that visitors can enjoy these previously misunderstood mammals.

Probably the most striking display of bat populations is in an arid desert region of New Mexico. At the large amphitheatre formed by the natural entrance to Carlsbad Caverns, visitors come in the evening to see hundreds of thousands of Mexican Freetail bats exit the cave, some pouring out of the entrance as numerous as 5,000 per minute in a great wave and in an undulating pattern appearing as smoke. The bats fly many miles each evening toward Mexico, and return again in the early morning hours. Carlsbad also holds restoration camps of volunteers who clear the cave of lint from visitors' clothing and restore areas beside the trails. 
Other conservation projects involve the protection of Native American artifacts, because as many as one-quarter of the show caves of the U.S. have been connected in some way with Indians.

The most effective form of preservation of caves comes under the heading of artificial caves, and one of the best U.S. examples was constructed under the Arizona desert. Using speleological consultants, the cave contains formations that are so well reproduced that a caver standing among them would feel right at home. There are over 15 artificial caves in the U.S.

A number of the country's show caves are protected by double glass entrance and exit doors. One example is Sonora Caverns in Texas. The doors help maintain the 98 percent relative humidity in room after room of snowwhite crystals, helictites, clear calcite wings on the wall, fields of calcite crystals, a butterfly speleothem, and countless other delicate features. Similar to other caves in the country, cave air and environmental conditions are being monitored. In Sonora, for maximum surveillance, visitor tours are confined to 12 persons.

And in the western volcanic rim of the U.S. there are many extinct and some active volcanos where travelers drive for miles throught old lava flows and walk near extinct craters. In Hawaii, volcanos are still fountaining, and it is possible to walk out on the lava and see the 2.000-degree-Fahrenheit magma flowing below. When the magma flows out, it leaves tunnels which after cooling have become interesting visitor trips. In the state of New Mexico, some of these tunnels exhibit ice stratas that are over 1,000 years old. Because of low population density in western regions, self- guided tours are used, and visitors often supply their own lights or may rent lanterns from a park headquarters.

Spelunking tours are offered throughout the U.S. and while these are sometimes controversial because of the effect they may have on the cavern environment, in Moaning Cave in California there is little effect on the cave because the visitor does not walk underground. He rappels downward 54 meters on a rope.

And farthest west at the edge of the Pacific Ocean, large mammals live along the rocky shore. Over 600 sea lions make the area in and near Sea Lion Caves, Oregon, their home. Visitors take an elevator down over 70 meters to a sea cave where the animals (some weighing as much as a ton) are separated from visitors by a glass partition. The sea lions continue their life cycles undisturbed, and visitors witness this cave and the mammals at close range.

The caves mentioned are only a few of the several hundred show caves of the U.S. but they give some special considerations. It will be the global objective of cave owners and operators to continue to improve methods for giving the maximum enjoyment to the visitor without jeopardizing the quality of the underground environments of the world's most rare and treasured caverns. 